\title{
PGS-AgrEvo deal stirs up plant biotechnology
}

Hoechst Schering AgrEvo's (AgrEvo, Berlin, Germany) $\$ 730$ million acquisition of PGS International (Amsterdam, the Netherlands) in August was not only the largest ever acquisition of a privately owned biotechnology company; It also greatly increased the likelihood that other plant and agricultural biotechnology companies could soon be swallowed by major corporations.

AgrEvo's move on PGS was not especially surprising. Multinational agrochemical companies have been building up their plant biotechnology expertise recently by acquiring plant biotechnology companies. Fearing that it was falling behind Monsanto (St. Louis, MO) and Novartis (Basel, Switzerland), AgrEvo was known to be interested in adding to its own portfolio. The choice of PGS was not a surprise either: The BelgianDutch plant biotechnology concern had developed the technology for producing crops tolerant to the AgrEvo broad-spectrum herbicide, Basta. What was surprising was the valuation the deal put on PGS and its technology.

Plant biotechnology companies have always been the poor relations of biopharmaceutical companies. They have not generated enthusiasm within the investment community. PGS attempted to float its shares on NASDAQ (North American Securities and Dealers Automated Quotation) two years ago-but failed. Its timing was bad, but even if it had succeeded it would have had a market capitalization of only around \$200-250 million. The only profit for investors in plant biotechnology has been in selling their shareholdings in agrochemical, food, and seed companies. AgrEvo's $\$ 730$ million bid for PGS demonstrates that this approach can pay off for patient investors.

AgrEvo announced it was bidding $\$ 550$ million for $75 \%$ of PGS shares with a commitment to tender for the remaining shares of PGS at an equivalent consideration. PGS employees hold about $10 \%$ of the company's shares while a further $15 \%$ is held by about 120 additional shareholders. That offer was the result of a closed bidding process that reportedly involved a number of AgrEvo's rivals: Bayer (Cologne, Germany), Du Pont (Wilmington, DE), Monsanto (St. Louis, MO), and Zeneca (London). AgrEvo's acquisition might be interpreted therefore as a defensive move to ensure that one of its rivals did not get its hands on technology that is key to the future of AgrEvo's plant biotechnology ambitions. With PGS's assets worth only about $\$ 30$ million, AgrEvo's bid values its technology at some $\$ 700$ million.
AgrEvo, like other agrochemical concerns, believes that its future success-or survival even-will depend on access to patent-protected plant biotechnology, especially in the areas of herbicide tolerance and pest protection. AgrEvo believes the global market for genetically modified plants will be worth $\$ 6$ billion by 2005 and that the PGS acquisition gives it the technological critical mass to command at least $\$ 1$ billion of that. AgrEvo chairman and CEO Gerhard Prante says, "This acquisition is part of an innovative strategy for growth at AgrEvo and allows us to build quickly the critical mass required to compete at a global level in plant biotechnology."

The real target for AgrEvo is probably not the Basta-tolerance technology, but PGS's position in insect-resistance technologies based on the Bacillus thuringiensis (Bt) toxin gene. The world's first insect-resistant plant was developed at PGS in 1985. The company received its first broad patent on insect resistant plants in 1993 and has been steadily reinforcing its patent estate ever since. PGS scientists have identified and patented several $B t$ genes, which encode for proteins toxic to the corn borer, of which the crylAb gene is most widely used by companies developing insect tolerant varieties. Indeed, just days before the AgrEvo announcement, the US Patent and Trademark Office (Washington, DC) issued a patent to PGS covering truncated cryl Ab proteins produced under the control of plant promoters. PGS has also recently discovered and engineered into corn another Bt gene, cry9C, which shows activity against the corn borer as well as several other important corn pests.

These two genes, cryl Ab and cry9C, can be used in combination as part of an insect-resistance management program. PGS even has a patent on resistance-management technology, according to Walter de Logi, managing director and CEO of PGS. More importantly, PGS now has a very strong grip on the development of $B t$ modified plants, and has patented or licensed in every element required for a $B t$ product. PGS is currently engaged in patent infringement litigation against Ciba Seeds (Basel) and Mycogen Plant Science (San Diego, CA) in the US District Court for the Middle District of North Carolina and has filed a motion to add its new US patent to its suit.

It is intended that AgrEvo will retain PGS's staff, although they will be joined by AgrEvo employees. The facilities in Ghent, Belgium, will become a center for AgrEvo's plant biotechnology activities.
AgrEvo's bid for PGS and the price it was willing to pay for the plant biotechnology company and its technology caused a great stir at other European plant biotechnology companies. Mogen International (Leiden, the Netherlands) released a statement shortly after the AgrEvo-PGS deal was announced saying that it was investigating opportunities to sell the whole company to a multinational partner. That news sent the price of stock in the company, which is traded on the market for unlisted securities on the Amsterdam Stock Exchange, to Dfl.18 (US\$10.64), nearly six times higher than a year earlier.

Arie Breure, Mogen's managing director, explained that the board of supervisory directors and management made the decision in response to pressure from stockholding institutional investors: "The company's strategy has always been to develop strategic alliances, and we have rejected offers from partners that had expressed interest in acquiring the whole company. However, with the sale of PGS our institutional shareholders questioned whether we would consider a sale. . . The board [has now] decided that it would. .."

Mogen's management is confident that it can build a sustainable business as an independent concern if need be, but with all the consolidation that is now taking place in the agrochemical and plant biotechnology sectors, that situation is unlikely to arise. For other companies the situation is not yet clear. GX BioSystems (Copenhagen, Denmark), which is building a business around a broad-based core technology for the active biological containment of genetically modified organisms (GMOs) to develop live GMO-based biopesticides, is still probably too small to attract the attention of multinationals, concedes managing director Neil Goldsmith. Nevertheless, Goldsmith believes the agrochemical sector's interest in plant biotechnology does create the opportunity for someone to pull together a number of small niche players and create a company with a broad portfolio of technologies, know-how, and patents.

Such a move would be closely followed by the management buyout team at Axis Genetics (Babraham, UK), which recently bundled all its plant gene technologies and patents into a spinout company, Pestax (Babraham). Given the premiums agrochemical firms now look like they are willing to pay for technology, the price paid by the Axis team when it spun off from AGC (Cambridge, UK) could turn out to be a bargain.

Mike Ward 